\title{
SAMUEL BECKETT CORRESPONDS WITH FATHER DAMIEN ON MOLOKAI.
}

The exoticism of place and people has nothing on the exotic nature

of experience.

He said.

This disease comes wrapped ornately:

non-native, inhabiting, like you,

your own parcel.

180

And there, too, you, lifting yourself

as a gift from the selfsame box, wrappings

drooping aside.

You, correspondingly, as background-

all palm, surf, and volcano.

In the foreground you stand holding

the present you are

before the recipient you

are, like

a garment

the birthday boy drapes across his chest, speculating on fit.

Yes, a birthday, I realize - that's what it is-

The alien nakedness of self to self. 
The candles redundant in the balmy weather.

The breath peeling itself away from deadened tissue, whereas the lung extinguishes the light with its own rare, numb substance. 